\title{
Crop-raiding deterrents around Budongo Forest Reserve: an evaluation through farmer actions and perceptions
}

\author{
Sara S. Hsiao, Caroline Ross, Catherine M. Hill and Graham E. Wallace
}

\begin{abstract}
Crop-raiding by primates and bushpigs Potamochoerus porcus is a major cause of human-wildlife conflict around Budongo Forest Reserve, Uganda. In 20062007 a project was initiated, with farmer participation, to investigate the efficacy of on-farm techniques to reduce crop-raiding, including guarding and early-warning techniques, fences, plant barriers, trenches, lights and nets. Here, farmers' perceptions of the effectiveness and sustainability of these deterrents were evaluated using semi-structured interviews and direct observations. Factors important to farmers in effective, sustainable and locally appropriate crop-raiding mitigation are that deterrents be cost-effective, easily manipulated, improve guarding efficiency and require minimal labour inputs. Farmers reported paid guards, guard dogs, wire fences, lights and bells/alarms as most effective. This differs from observations that farmers independently maintained certain deterrents that they presumably considered valuable, namely wire fences, guard dogs, bells/ alarms, trenches, lights and nets. This evaluation demonstrates the importance of farmers' participation and perceptions in the viability and uptake of crop-raiding deterrents, and the importance of assessing conflict mitigation trials over the long term.
\end{abstract}

Keywords Budongo Forest Reserve, conservation, crop protection, crop-raiding, human-wildlife conflict, Uganda

\section{Introduction}

Crop-raiding by wildlife causes considerable humanwildlife conflict, particularly when people farm near wildlife refuges. Increasing human populations, migration to forested areas, and intensification, expansion and commercialization of agriculture all increase crop production. This results in crop-raiding because animals are forced to rely on crops when wild forage diminishes, or

SARA S. HSIAO* (Corresponding author) and CAROLINE Ross Centre for Research in Evolutionary Anthropology, Department of Life Sciences, Roehampton University, London, UK. E-mail sara@janegoodall.ca

Catherine M. Hill and Graham E. Wallace Anthropology Centre for Conservation, Environment and Development, Department of Anthropology and Geography, Oxford Brookes University, Oxford, UK

${ }^{*}$ Present address: The Jane Goodall Institute of Canada, c/o University of Toronto Mailroom, 563 Spadina Crescent, Toronto, Ontario M5S 2J7, Canada

Received 9 December 2011. Revision requested 10 April 2012.

Accepted 6 June 2012. First published online 22 July 2013. because animals prefer crops to wild foods (NaughtonTreves et al., 1998; Dixon et al., 2009). Resulting conflict between farmers and wildlife decreases farmers' tolerance of wildlife, undermining local support for conservation (Hill et al., 2002). To compensate for increasing risk of crop loss, farmers may extend their farms into wildlife habitats and/or use deterrent methods that are often lethal and not speciesspecific (Hill, 2004; Dixon et al., 2009). Furthermore, the increasing frequency of human-wildlife interactions promotes greater risk of disease transmission (Goldberg et al., 2007). Therefore, reducing crop-raiding by wildlife may alleviate a significant proportion of local human-wildlife conflict to the benefit of conservation efforts.

Vulnerability to crop-raiding is influenced by many factors, including wildlife species present, proximity of farms to forest, proximity of nearest neighbouring farm, and human density and migration patterns (Newmark et al., 1994; Hill, 1997; Paterson, 2005). Cultural differences in perceptions and reactions towards species also influence whether farmers regard species as problematic and/or acceptable prey (Chalise \& Johnson, 2005; Fernando et al., 2005).

Several studies have tested deterrents such as translocations, conditioned taste aversion, training problem animals, and electric fences (Forthman Quick, 1986; Biquand et al., 1994; Strum, 1994; Thouless \& Sakwa, 1995). However, evaluation reports of mitigation trials are limited and focus on crop-raiding by elephants (Sitati \& Walpole, 2006; Graham \& Ochieng, 2008). Evaluation is essential to identify locally appropriate strategies that support long-term conservation.

This study investigated farmers' perceptions of cropraiding deterrent techniques tested on 11 farms around Budongo Forest Reserve in Uganda. We aimed to assess (1) whether farmers using deterrents were more likely to report enhanced crop yield than neighbouring farmers not using deterrents, (2) farmers' perceptions of the effectiveness of a variety of deterrents over time, (3) farmers' attitudes to deterrent maintenance and sustainability over time, and (4) whether some deterrents are locally more useful than others.

\section{Study area}

The study was conducted in five villages of Nyabyeya Parish, around southern sections of Budongo Forest Reserve. The villages are ethnically diverse and home to Lugbara, 


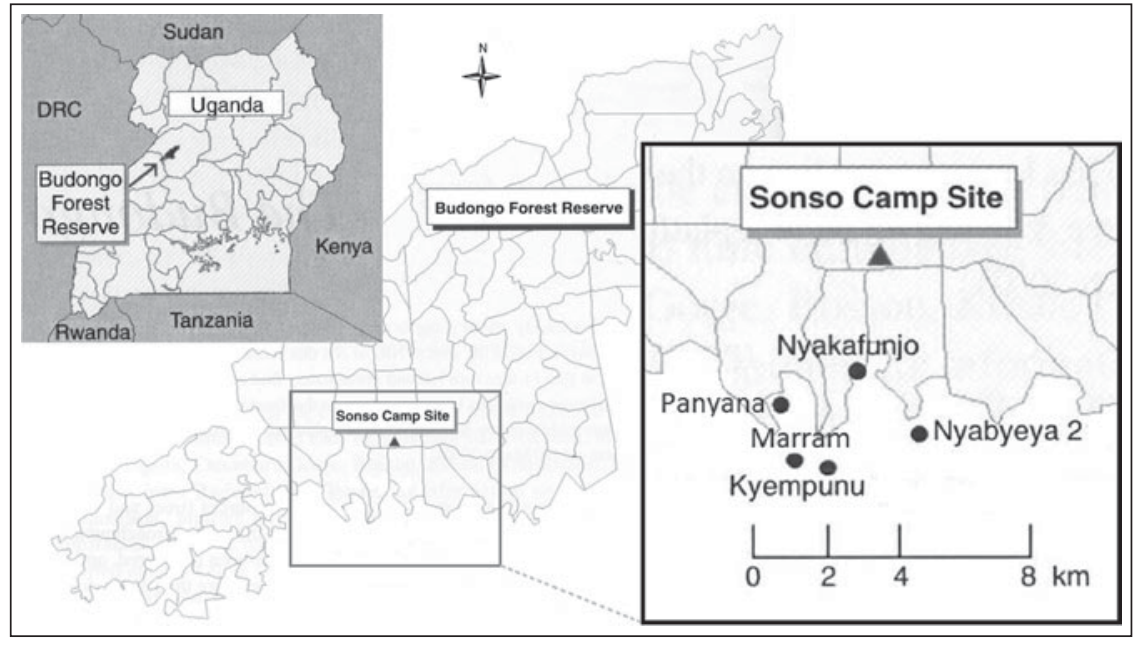

FIG. 1 Budongo Forest Reserve, showing the locations of the five villages where this study took place. The inset indicates the location of Budongo Forest Reserve in Uganda. Modified from Reynolds (2005).
Alur, Kakwa, Lendu and Banyoro people (Paterson, 2005). Economic growth in the area and civil unrest has led to an influx of migrants over the past half century (Paterson, 2005). Communities around the Reserve depend on subsistence agriculture, and crop-raiding is perceived as the greatest challenge of living close to the forest (Hill, 2000; Webber, 2006). People are aware of the natural value and potential wildlife-oriented employment benefits of the forest (Johnson, 1993) but value wildlife most for meat (Webber, 2006).

Earlier studies demonstrated that olive baboons Papio anubis and bushpigs Potamochoerus porcus cause the majority of crop losses (Hill, 2000; Webber, 2006). However, redtail monkeys Cercopithecus ascanius schmidti, blue monkeys Cercopithecus mitis stuhlmannii and vervet monkeys Chlorocebus aethiops have recently been observed to cause similar or more damage than baboons (Wallace, 2010). There is increasing antagonism towards chimpanzees Pan troglodytes schweinfurthii, who raid sugar cane but cause relatively minor damage and rarely visit farms (Hill, 2004; Webber, 2006).

Maize, cassava and beans are the most important staple crops raided by animals (Hill, 2000). Farmers' perceptions of raiding wildlife are influenced by observable raiding events, previous interactions with wildlife, and cultural beliefs, all of which can affect how conflict mitigation strategies are executed and received locally (Wallace, 2010). Previous research at this site highlighted obstacles to long-term wildlife control, particularly the lack of (1) involvement of key stakeholders, (2) objective evaluation of intervention costs and benefits, (3) participatory monitoring and evaluation, and (4) long-term funding commitment (Webber et al., 2007).

\section{Methods}

During 2006-2007 GEW and CMH developed and tested crop-raiding deterrents on 11 farms in five villages around
Budongo Forest Reserve (Fig. 1). Selection of farms was based originally on proximity to and view of forest edges, crops grown, farm dimensions, and farmers' willingness to participate in the research (Table 1). Deterrents introduced in 2007 (Table 2) were based on data from 2006 and farmers' recommendations during focus group sessions. Assessment over the first season of testing these techniques showed they were effective in reducing raid frequencies and/or crop damage in almost all cases (Hill \& Wallace, 2012).

The follow-up study (March-May 2008) reported here was conducted by SSH and CR to provide an independent evaluation of farmers' perceptions of the crop-raiding deterrents implemented (Hsiao, 2008); SSH and CR were not associated with the previous research and did not have prior experience of working with the farmers.

The study was approved by the Roehampton University ethics board, and granted research permission by the Uganda National Council for Science and Technology and the Ugandan Wildlife Authority. Farmers consented verbally to participation in the research, as many people in the area are illiterate and an oral tradition predominates (Webber, 2006). Participants were free to withdraw at any time. The purpose, methods, and preliminary findings of the investigation were explained to all participants in local languages.

With approval by each village chairperson the 11 farmers involved with deterrent testing during 2007 were invited to participate in the present study. Additionally, the owners of farms neighbouring each of the deterrent farms and also at the forest edge were invited to participate, giving a total of 22 farms (11 'deterrent farms' and 11 'neighbouring farms').

Semi-structured interviews and informal discussions with farmers were conducted in Kiswahili, English or Alur, with assistance of a translator, to gauge farmers' evaluations of deterrents. Open-ended questions and a conversational style were used to minimize researcher bias and elicit farmers' knowledge (Bryman, 2001). Interviews were 
TABLE 1 Descriptions of farms in 2008, one year after deterrents were introduced. Farms are numbered in the order they were recruited in the 2007 study (Wallace, 2010).

\begin{tabular}{rlllr}
\hline Farm no. & Village & Distance from forest edge* $(\mathrm{m})$ & Crops grown & Area $^{\left(\mathrm{m}^{2}\right)}$ \\
\hline 1 & Nyakafunjo & 0 & Soya beans & 25,378 \\
2 & Nyakafunjo & 0 & None & 11,283 \\
3 & Nyakafunjo & 0 & Maize, beans, sweet potato, cassava & 25,439 \\
4 & Marram & 0 & Maize, cassava, potato & 19,755 \\
5 & Marram & 0 & Maize, beans, cassava & 8,487 \\
6 & Panyana & $20+$ (medium grass) & Maize, beans, sorghum & 26,921 \\
7 & Panyana & $30+$ (overgrown grass) & Maize, beans, rice, sorghum & 36,104 \\
8 & Kyempunu & Indistinguishable (no forest) & Maize, sugar cane, yam, banana & 12,327 \\
9 & Kyempunu & $20+$ (short grass) & Maize, rice & 37,736 \\
10 & Nyabyeya II & 0 & Maize, beans & 18,414 \\
11 & Nyabyeya II & 0 & Maize, beans, tobacco & 22,587 \\
\hline
\end{tabular}

${ }^{\star} 0 \mathrm{~m}$, farm directly adjacent to forest without any buffer zone; type of grass in buffer zone refers to amount of forest visibility from farm edge (i.e. short, perfectly visible; medium, less visibility; overgrown, visibility difficult); indistinguishable, farm and forest boundaries cannot be discriminated

TABLE 2 Description and rationale for use of introduced deterrents, and distribution across the 11 deterrent farms (numbers as in Table 1). Modified from Wallace (2010).

\begin{tabular}{|c|c|c|c|}
\hline Deterrent & Description & Rationale for use & $\begin{array}{l}\text { Introduced } \\
\text { on farms }\end{array}$ \\
\hline Paid guards & $\begin{array}{l}\text { People paid to patrol on farms, shout at \& chase away } \\
\text { wildlife that enter farms }\end{array}$ & $\begin{array}{l}\text { Ensuring that crop-raiding animals do not enter } \\
\text { farms, \& reducing guarding time for farmer }\end{array}$ & 3,6 \\
\hline Guard dogs & Domestic dogs & Alert farmers to wildlife \& chase wildlife away & 3,8 \\
\hline $\begin{array}{l}\text { Barbed wire } \\
\text { fence }\end{array}$ & Fences made from wooden posts \& barbed wire & Barriers to keep wildlife out of farms & $1,3,6,7$ \\
\hline $\begin{array}{l}\text { Net wire } \\
\text { fence }\end{array}$ & Fences made from wooden posts \& wire netting & Barriers to keep wildlife out of farms & $1,4,10,11$ \\
\hline Rope fence & Fences made from wooden posts \& rope & Barriers to keep wildlife out of farms & 2,6 \\
\hline $\begin{array}{l}\text { Ocimum } \\
\text { border }\end{array}$ & $\begin{array}{l}\text { Aromatic shrub (Ocimum kilimandscharicum) } \\
\text { planted to surround portions of farms }\end{array}$ & Barriers to keep wildlife out of farms & $4,5,11$ \\
\hline $\begin{array}{l}\text { Jatropha } \\
\text { border }\end{array}$ & $\begin{array}{l}\text { Hearty plant (Jatropha curcas) with toxic compounds } \\
\text { planted to surround portions of farms }\end{array}$ & Barriers to keep wildlife out of farms & 7 \\
\hline Trench & Extended pit dug around portions of farms & Barriers to keep wildlife out of farms & 5 \\
\hline Bells/alarms & Variety of objects that sound out & $\begin{array}{l}\text { Alert farmers to wildlife presence \& frighten } \\
\text { wildlife away }\end{array}$ & 1,6 \\
\hline Lights & Battery/solar powered lights & Simulate human presence at night & 11 \\
\hline Net & Mesh netting strung over wooden poles & To cover growing rice (from birds) & 9 \\
\hline
\end{tabular}

conducted at times convenient for farmers, on their farms, to enable farmers to demonstrate deterrents and farm features, and for assessment by the interviewer. Each farm was visited at least once to conduct interviews, which were hand written, to maintain an informal environment. Deterrent farms were visited on at least four further occasions to map deterrents and observe their use.

Guiding questions were followed with all farmers (Table 3), with most questions designed to elicit a qualitative response. Each farmer was also asked to estimate their relative crop yield in 2007 compared with previous years without introduced deterrents. Actual crop yields were not required (although some quantitative estimates were offered; e.g. 10 bags of maize vs two) as farmers' responses were compared with their other assessments and actions, to further indicate perceived deterrent effectiveness.
Observations assessed which deterrents were maintained or modified for ongoing use. The location of deterrents established in 2007 was known from coordinates recorded with a global positioning system (Wallace, 2010); any new deterrents were recorded. Differences between the number of deterrents on farms in 2007 and in 2008 were tested using the Wilcoxon's Signed Rank test.

Key themes emphasized by farmers in interviews and discussions were categorized according to perceived deterrent effectiveness, and issues of deterrent maintenance and sustainability. Data collected on this small sample does not verify actual deterrent effectiveness (e.g. through actual crop loss) but is analysed to assess considerations that inform farmer perceptions of deterrent effectiveness and how their actions relate to this. Not all 22 farmers had deterrents on their farm but all were asked to provide feedback about 
TABLE 3 Guiding questions to farmers with introduced deterrents $(n=11)$, and neighbouring farmers without formally-introduced deterrents $(\mathrm{n}=11)$.

\section{Farmers with introduced deterrents}

How much crop-raiding have you experienced since the deterrents were introduced?

How was your crop yield this past year compared to previous years?

Have deterrents been effective? How effective?

Which (combinations of) deterrents are most effective?

Is the level of investment worth the gain?

How easy/hard are they to maintain?

Will deterrents continue to be used on your own resources? To what degree?

How are you maintaining the deterrents?

Are there any changes of deterrent use from initial instalment?

Moved, modified, extended, etc?

Do protective measures differ in their effectiveness at different times of year?

Have you heard of any other methods being used? What other methods do you use?

Do you have any further ideas? Comments?

\section{Neighbouring farmers without formally-introduced deterrents}

Have you heard about and seen the deterrents? What have you heard/seen?

What does your neighbour say about his/her deterrents?

What do you think of the deterrents?

How effective do you think they have been?

Which (combinations of) deterrents are most effective?

Have you adopted any yourself?

Describe to me your deterrents. Are you using something just as effective? Better?

Have you heard of any other methods being used?

How much crop-raiding have you experienced since the deterrents were introduced?

How was your crop yield this past year compared to previous years?

Do you have any further ideas? Comments?

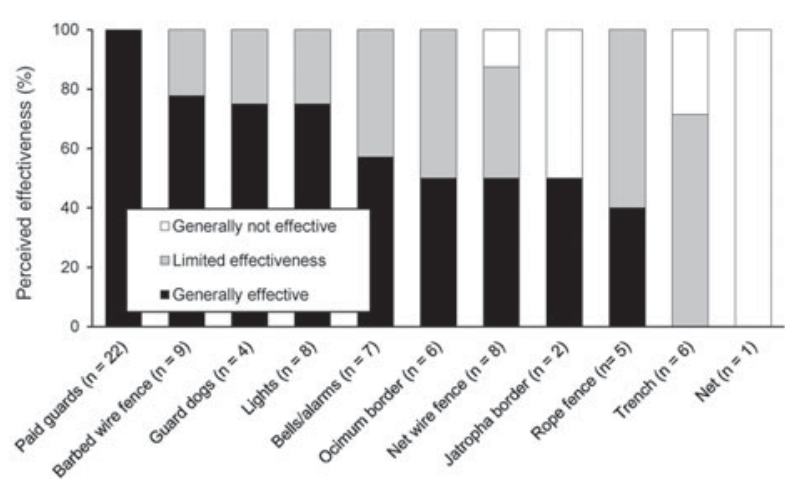

FIG. 2 Perceived effectiveness of introduced deterrents, based on number of farmer respondents.

deterrents because many had previous direct experience with different deterrents (Webber et al., 2007) and/or had indirect experience from observing neighbours' farms. Fisher's Exact or Mann-Whitney $U$ tests were applied to test for significant differences between responses by the two farmer groups.

\section{Results}

\section{Farmers' perceptions of deterrent effectiveness}

For deterrent farmers relative crop yield between years with and without tested deterrents had reportedly increased on all 11 farms. Of 11 neighbouring farmers, three declared higher yields, five reported no change, and three claimed lower yields. There is a significant difference in reported yields between deterrent and neighbouring farms (Fisher's Exact test, $\mathrm{P}=0.0005$ ). One neighbouring farmer reported increased crop-raiding because animals were redirected from his neighbour's protected farm. Conversely, other neighbouring farmers associated reduced or unchanged crop yields with poor soil quality, drought conditions and usual levels of crop-raiding. Although all deterrent farmers reported increased yields when using deterrents, only eight maintained the deterrents. The three farmers who did not maintain their deterrents associated this with lack of time and resources, and how effective the deterrents were perceived to be. Not all deterrents were discussed by all farmers, with 1-22 farmers mentioning each of the 11 introduced deterrents, and six of the 11 deterrents perceived to be effective overall (Fig. 2, Table 4). Paid guards were considered effective by all farmers because they can guard at all times, whereas farmers committed to other activities cannot. Most farmers stressed that guarding 'is essential' 'because you are assured of it', and it 'is definitely most effective for baboons'. Farmers identified disadvantages of guarding, including social costs because of restrictions on leaving farms, health risks from guarding in the rain and at night, and lost opportunities such as children not being able to attend school. 
TABLE 4 Farmer perceived benefits and drawbacks of introduced deterrents.

\begin{tabular}{|c|c|c|}
\hline Deterrent & Perceived benefits & Perceived drawbacks \\
\hline Paid guards & Assured protection once animal spotted & Monetary costs to hire guards \\
\hline Guard dogs & $\begin{array}{l}\text { Detect inconspicuous raiders before humans; } \\
\text { intimidating to some wildlife }\end{array}$ & Must maintain health; can be chased away by some wildlife \\
\hline $\begin{array}{l}\text { Barbed wire } \\
\text { fence }\end{array}$ & $\begin{array}{l}\text { Causes potential injury to wildlife; relieves guarding; } \\
\text { most durable fence design }\end{array}$ & High material costs; laborious to construct \& maintain \\
\hline $\begin{array}{l}\text { Net wire } \\
\text { fence }\end{array}$ & Causes potential injury to wildlife; relieves guarding & High material costs; laborious to construct \& maintain \\
\hline Rope fence & $\begin{array}{l}\text { Psychological barrier; substances can be smeared (e.g. } \\
\text { chilli grease) \& bells/alarms hung to deter animals }\end{array}$ & $\begin{array}{l}\text { High material costs; laborious to construct \& maintain; ropes } \\
\text { susceptible to thieves \& quickly destroyed by rain }\end{array}$ \\
\hline $\begin{array}{l}\text { Ocimum } \\
\text { border }\end{array}$ & Associated bees \& aroma repel wildlife; low maintenance & Animals easily habituated \\
\hline $\begin{array}{c}\text { Jatropha } \\
\text { border }\end{array}$ & Termite resistant \& long-lasting; low maintenance & Time required to become large enough; commitment needed \\
\hline Trench & Trapped animals can be killed; low maintenance cost & $\begin{array}{l}\text { Laborious to maintain; soil erosion \& affected by rain; limited } \\
\text { to bushpigs Potamochoerus porcus \& ungulates }\end{array}$ \\
\hline Bells/Alarms & $\begin{array}{l}\text { Early warning to improve guarding efficiency; relieves } \\
\text { need to chase wildlife }\end{array}$ & Susceptible to thieves; guarding still essential \\
\hline Lights & $\begin{array}{l}\text { Relieves night-time guarding; effective in all weather } \\
\text { conditions }\end{array}$ & $\begin{array}{l}\text { Susceptible to thieves; only effective at night; potentially high } \\
\text { material costs }\end{array}$ \\
\hline Net & None reported & Ineffective \\
\hline
\end{tabular}

Four respondents found guard dogs effective because they can detect crop raiders before humans, and may deter baboons from predating livestock. Although the dogs originally distributed to two farmers died their value was apparent to both farmers, who had acquired replacement dogs.

Seven of nine farmers who discussed barbed wire fences, and three of seven who discussed net wire fences, reported these methods generally effective because animals believe there 'is a trap' that could harm them. Three deterrent farmers indicated 'the fences are working so well... we are imitating them'. Five farmers used forest wood, metal and other materials to build and/or replace fences independently. Forest wood was widely stated by farmers to last at least three times longer than timber purchased locally. Although farmers estimated barbed wire would last for 5 years, obtaining replacements was not considered affordable. Several farmers measured fence effectiveness by the fact that people were 'relieved from very serious guarding' but thought fences were only effective against bushpigs, as monkeys simply 'use force and jump' or 'rip though the fence'.

Lights used at night were reported effective by eight farmers. They were thought to be the best protection against nocturnal animals, reducing night-guarding and associated risks of exposure to disease and injury. Neighbouring farmers up to $1 \mathrm{~km}$ away suggested the lights also deterred animals from their farms. The lights were maintained by the farmer, who retrieved them during the day to avoid theft.

Bells attached to fences were stated by seven farmers to improve guarding efficiency by alerting farmers to animal entry, and frightening animals already on farms so 'they do not need to be chased'. A farmer explained that bells were only placed on the fence when crops were becoming mature, to avoid habituation by animals and prevent weathering and theft.

Ocimum Ocimum kilimandscharicum borders were perceived as effective by six farmers. One farmer described how baboons 'feared' the ocimum because of potential negative interactions with bees, and two farmers suggested that baboons and bushpigs fear the novel 'smell' of ocimum because it 'is not in the forest'. Three farmers thought effectiveness was limited because monkeys did not 'know about the bees' or 'mind the smell', and simply jump over the border. One farmer predicted that baboons would eventually 'learn that [ocimum] cannot harm you and will begin entering [the farms]'.

The net wire fence had general or limited effectiveness according to seven farmers but was considered ineffective by one. Five farmers thought rope fences were effective but with more limitations than benefits because ropes are quickly destroyed by rain and so were not maintained. Limited longevity of ropes also restricted the use of bells and chilli paste, which were attached to or smeared on rope.

The jatropha Jatropha curcas border at one farm was considered ineffective. The farmer emphasized that 'only where [animals] feel pain, they stay away'. This farmer and one other, discussed how jatropha 'does not get broken' or 'eaten by termites', but 'takes many years to become big or effective enough' and 'lots of commitment is needed'.

Trenches were perceived to have limited effectiveness by five farmers, and considered ineffective by one. Trenches were perceived to deter only bushpigs who reportedly feared falling in and being 'trapped'. Using a trench 'about one 


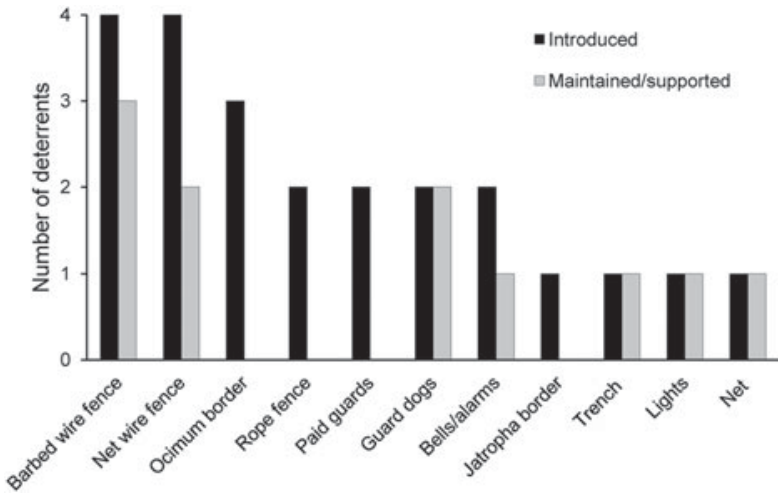

FIG. 3 Number of deterrents introduced compared with the number of deterrents maintained and/or supported (modified for further use).

metre deep and a half metre wide', particularly dug in a $\mathrm{V}$-shape, was said to prevent any bushpig from escaping, enabling farmers to kill them. However, one farmer suggested, 'the pigs have already learnt how to avoid trenches ... they level the ground with their snout and begin to pass'. The trench introduced at one farm was not maintained, although another trench had been dug on an adjacent area of the farm.

The farmer who used netting to protect rice claimed it was ineffective for deterring birds. However, to explain the poor yield the farmer reported 'the sunshine was too much, there was not enough rain, and I planted it too late'. Nevertheless, the farmer had maintained the net by storing it after harvest. At the end of observations the rice had just been planted and there was no indication whether the farmer intended to use the net again.

\section{Deterrent maintenance and sustainability}

Eight of 11 farmers maintained their deterrents (Fig. 3). Three farmers did not maintain deterrents although two stated their intention to make modifications and/or extensions to them. There were no significant differences between the number of deterrents initially introduced in 2007 and the number observed in $2008(\mathrm{Z}=-0.53, \mathrm{n}=11$, $\mathrm{P}=0.59$ ).

Five issues were identified by farmers as long-term sustainability concerns: costs, weather, labour, termite damage and theft (Fig. 4). Monetary costs were highlighted as a major problem, particularly the costs of materials such as barbed wire, ropes and chemical treatments for wooden posts. Rain causes deterioration of rope fences and soil erosion of trenches, and locally, people associate exposure to rain (e.g. when guarding) with an increased risk of illness. Additionally, guard huts reportedly last only 6-12 months before being 'thrown down by wind'. Labour needed to sustain particular deterrents, such as building/maintaining fences, digging trenches and guarding was also identified as

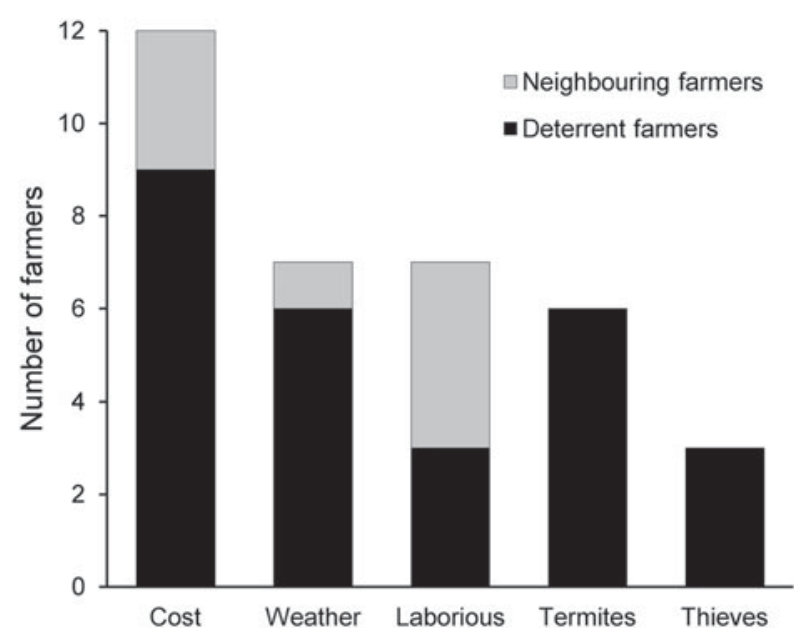

Fig. 4 Issues of deterrent sustainability discussed by farmers overall $(\mathrm{n}=22)$, and between deterrent farmers $(\mathrm{n}=11)$ and neighbouring farmers $(n=11)$. No significant difference between issues were identified by deterrent and neighbouring farmers.

a concern, along with the problem of termites reducing the longevity of wooden structures (fence posts, guard huts). Several individuals noted the risk of thieves removing deterrents from farms, such as bells, lights and rope. There was no significant difference between the total number of issues identified by deterrent and neighbouring farmers $(Z=-1.00, \mathrm{n}=22, \mathrm{P}=0.32)$.

\section{Discussion}

\section{Farmers' perceptions of deterrent effectiveness}

Farmers using deterrents were more likely to report enhanced crop yield between years than were neighbouring farmers who did not participate in the original intervention programme. Although perceived benefits of the deterrents were significant it is possible cash-poor farmers are motivated to respond in a way that may result in additional financial support for conflict mitigation. However, the majority of neighbouring farmers estimated no change in their crop yields; yet during the initial study, unprotected neighbouring farms did experience increased crop-raiding (Wallace, 2010). Consequently, it is unlikely that farmer feedback was solely motivated by the possibility of receiving assistance on their farm.

Deterrents perceived as most effective were primarily those increasing farmers' guarding efficiency and/or causing minor injury to wildlife. Guarding is the most common crop-protection method that farmers claim to use at this and other sites (Naughton-Treves, 1997; Hill, 2000; Warren et al, 2007). However, there is little evidence that farmers actively engage in extended periods of guarding around Budongo Forest Reserve (Wallace, 2010). Farmers provided few insights about why they did not guard cooperatively, 
which may provide better protection (Warren et al., 2007), besides suggesting it is difficult to coordinate farmer schedules. Guard dogs and alarm bells were generally well received, as they were thought to aid early detection of animals and enhance guarding efficiency. Elsewhere, farmers also value early warning and guarding effort to deter animals ranging in size from monkeys to elephants (Watanabe \& Muroyama, 2005; Sitati \& Walpole, 2006).

People traditionally burn fires to threaten nocturnal raiding species (Hill, 1997; Sitati \& Walpole, 2006). Use of solar lights is comparable to this method but more reliable during rain or windy conditions, and requires no fuelwood. Costs for maintaining solar-charged batteries or replacing lights have not been calculated but probably exceed those of using fires. However, the benefits were perceived to accrue to numerous farmers, and the reduced environmental impacts of this method suggest it could be a viable option for widespread use.

Barrier methods of crop protection are passive strategies that allow farmers to conduct other activities, and provide a physical and psychological barrier and thus generally have good perceived effectiveness (Thouless \& Sakwa, 1995). Although material costs of trenches are low (Hill et al., 2002), results confirm several perceived drawbacks limiting use by farmers, including erosion by water, maintenance effort, and because certain species can traverse them (Mascarenhas, 1971; Thouless \& Sakwa, 1995).

Plant borders also provide a physical barrier separating farms from forest and thus may relieve costs associated with guarding. These barriers probably impose limited risk for animals entering farms but are inexpensive to erect (Wallace, 2010). They are most effective when at maximum density and height and/or full of flowers and bees; even the sound of bees and presence of beehives can deter elephants (Karidozo \& Osborn, 2005; King et al., 2007). The droughtand pest-resistant characteristics of jatropha (USDA, 2008) and similar plants, are important advantages as deterrents; one farmer identified jatropha as good material for fence posts. Farmers did not mention minimal maintenance and the self-propagating nature of plant borders as a benefit, and did not maintain hedges. However, one farmer intended to spread ocimum seedlings around his farm because he thought the border effective. Similarly, Mauritius thorn Caesalpinia decapetala and sisal hedges Agave sisalana have reduced crop-raiding effectively in Uganda and Tanzania but farmers are reluctant to maintain them, for unidentified reasons (Mascarenhas, 1971; Biryahwaho, 2002).

\section{Deterrent maintenance and sustainability}

Seven of the trialled deterrents were maintained or supported: barbed wire fences, net wire fences, dogs, bells/ alarms, trenches, lights and nets. Several farmers also built extensions of fences and trenches or added additional fencing. There was no evidence of maintenance or support for plant borders, rope fences, or paid guards. Farmers indicated that rope fences and paid guards were not affordable. However, other types of fences were maintained, perhaps reflecting farmers' perceptions of their effectiveness as more robust physical barriers against animals and humans.

Data from a complete growing season confirm deterrents were effective in reducing crop-raiding (Hill \& Wallace, 2012). Very likely however, part of the attractiveness to farmers to initially test the deterrents was the free assistance they received to protect their crops. Hence, the relative importance of the different sustainability factors is difficult to determine in this small-scale study. Nevertheless, it is still clear that certain factors are important to farmers when assessing deterrents' long-term value, namely cost and durability. A study of farmers reported that those who expressed positive views of particular deterrents were willing to make financial commitments towards sustaining future trials (Graham \& Ochieng, 2008). Thus, farmers' perceptions of and experiences with crop-protection methods play an important role in the long-term viability of deterrent strategies.

Farmers perceive cost-efficient methods as highly valuable. As identified at this site and elsewhere, household labour availability is a key factor (Naughton-Treves, 1997; Hill, 2004; Graham \& Ochieng, 2008), particularly in relation to guarding and replacing fences. Termites affect longevity of wooden structures but many farmers are relatively tolerant of termites and other insects because they are consumed. Using other materials, such as termiteresistant jatropha stems would reduce this problem. Weather also affects the longevity of deterrents and hence their effectiveness. Theft and weather were highlighted by Webber (2006) as 'external' issues (i.e. those outside farmers' control) and thus often perceived as more severe than 'internal' issues, which occur within farm boundaries and are viewed to be more controllable by farmers. Cost of materials would also fit within this paradigm, as an 'external' issue, outside farmers' control.

High costs probably explain why farmers do not pay guards. The costs of all deterrents were covered by the original project (Wallace, 2010); in most cases farmers did not spend their own money on maintaining them but instead used forest or scrap materials to repair fences, or took good care of the materials originally supplied (nets, lights). It is not clear whether these farmers would continue to maintain these deterrents if cash outlay was necessary.

'Natural' barriers (plant borders, trenches) may be viable options for further investigation. Although farmers perceive these methods as having variable or limited effectiveness, they are more sustainable in terms of costs and reduce extraction of forest resources. Firewood is becoming 
increasingly difficult to locate in the study area (Klunne \& Mugisha, 2001) and people in one village travel long distances to collect firewood (A.H. Fani, pers. comm. 2008). Thus, further extraction of forest resources for deterrent materials is not sustainable in the longer term.

\section{Suggestions and considerations}

The results demonstrate that taking farmer perceptions of effectiveness and sustainability into consideration is an essential component of designing strategies that will be successfully maintained once outside involvement is reduced. As reported elsewhere, a flexible and varied range of locally appropriate, practical techniques and management strategies may be the key to deterring crop-raiding animals, as no single strategy has proven prolonged effectiveness (Watanabe \& Muroyama, 2005; Warren et al., 2007; Graham \& Ochieng, 2008). The idiosyncrasies of different farm conditions and different farmers' needs and perceptions may be catered for if the techniques used are varied. However, deterrents must be cost-effective and easily manipulated or transferred if farmers are to find time and resources to maintain them. Although the current study is relatively small it indicates that testing and positive demonstration may encourage uptake of deterrents by farmers. Potential strategies may lie in further examination of methods that reduce the costs of potentially expensive deterrents (e.g. fences, dogs, lights) perceived to be useful and worth maintaining, increased use of natural barriers, and implementation of more efficient guarding techniques.

\section{Acknowledgements}

Many thanks to H. Biroch, A.H. Fani and A. Geoffrey for their hard work on this project, which was supported by the International Primatological Society and American Society of Primatologists. We are grateful to the people of Nyabyeya Parish, the staff at the Nyabyeya Forestry College, and everyone at Budongo Conservation Field Station. SSH would particularly like to thank C. Crockford and R. Wittig for their guidance and invaluable feedback in the field. We thank D. Wong and T.C. Rae for their assistance with the figures.

\section{References}

Biquand, S., Boug, A., Biquand-Guyot, V. \& Gautier, J.P. (1994) Management of commensal baboons in Saudi Arabia. Revue d'Ecologie-La Terre et la Vie, 49, 213-222.

Biryahwaho, B. (2002) Community perspectives towards management of crop-raiding animals: experience of Care-DTC with communities living adjacent to Bwindi Impenetrable and Mgahinga Gorilla National Parks, Southwest Uganda. In Human-Wildlife Conflict: Identifying the Problem and Possible Solutions. Albertine
Rift Technical Report Series Vol. 1 (eds C.M. Hill, F.V. Osborn \& A.J. Plumptre), pp. 47-57. Wildlife Conservation Society, New York, USA.

Bryman, A. (2001) Social Research Methods. Oxford University Press, Oxford, UK.

Chalise, M.K. \& Johnson, R.L. (2005) Farmer attitudes toward the conservation of 'pest' monkeys: the view from Nepal. In Commensalism and Conflict: The Human-Primate Interface (eds J.D. Paterson \& J. Wallis), pp. 222-239. American Society of Primatologists, Oklahoma, USA.

Dixon, A.B., Hailu, A., Semu, T. \& Taffa, L. (2009) Local responses to marginalisation: human-wildlife conflict in Ethiopia's wetlands. Geography, 94, 38-47.

Fernando, P., Wikramanayake, E., Weerakoon, D., Jayasinghe, L.K.A., Gunawardene, M. \& JanaKa, H.K. (2005) Perceptions and patterns of human-elephant conflict in old and new settlements in Sri Lanka: insights for mitigation and management. Biodiversity and Conservation, 14, 2465-2481.

Forthman Quick, D.L. (1986) Controlling primate pests: the feasibility of conditioned taste aversion. In Current Perspectives in Primate Social Dynamics (eds D.M. Taub \& F.A. King), pp. 252-273. Van Nostrand Reinhold, New York, USA.

Goldberg, T.L., Gillespie, T.R., Rwegod, I.B., Wheeler, E., Estoffa, E.L. \& Chapman, C.A. (2007) Patterns of gastrointestinal bacterial exchange between chimpanzees and humans involved in research and tourism in western Uganda. Biological Conservation, $135,511-517$.

Graham, M.D. \& OChienG, T. (2008) Uptake and performance of farm-based measures for reducing crop-raiding by elephants Loxodonta africana among smallholder farms in Laikipia District, Kenya. Oryx, 42, 76-82.

HILL, C.M. (1997) Crop-raiding by wild vertebrates: the farmer's perspective in an agricultural community in western Uganda. International Journal of Pest Management, 43, 77-84.

Hill, C.M. (2000) Conflict of interest between people and baboons: crop-raiding in Uganda. International Journal of Primatology, 21, 299-315.

Hill, C.M. (2004) Farmers' perspectives of conflict at the wildlife-agriculture boundary: some lessons learned from African subsistence farmers. Human Dimensions of Wildlife, 9, 279-286.

Hill, C.M., Osborn, F.V. \& Plumptre, A.J. (eds) (2002) Human-Wildlife Conflict: Identifying the Problem and Possible Solutions. Albertine Rift Technical Report Series Vol. 1. Wildlife Conservation Society, New York, USA.

Hill, C.M., \& Wallace, G.E. (2012) Crop protection and conflict mitigation: reducing the costs of living alongside non-human primates. Biodiversity and Conservation, 21, 2569-2587.

Hsiao, S.S. (2008) Evaluation and monitoring of crop-raiding mitigation strategies in villages around Budongo Forest Reserve, Uganda. MRes thesis. Roehampton University, London, UK.

Johnson, K.R. (1993) Local use of Budongo's forest products. MSc thesis. Oxford University, Oxford, UK.

Karidozo, M. \& Osborn, F.V. (2005) Can bees deter elephants from raiding crops? An experiment in communal lands of Zimbabwe. Pachyderm, 39, 26-32.

King, L.E., Douglas-Hamilton, I. \& Vollrath, F. (2007) African elephants run from the sound of disturbed bees. Current Biology, 17, R832-R833.

Klunne, W. \& Mugisha, C. (2001) Responses of rural households to the decline of woodfuel collecting areas: case study in an expanding sugarcane area in the Masindi District of Uganda. Energia, 4, 7-9.

Mascarenhas, A. (1971) Agricultural vermin in Tanzania. In Studies in East African Geography and Development (ed. S.H. Ominde), pp. 259-267. Heinemann, London, UK. 
Naughton-Treves, L. (1997) Farming the forest edge: vulnerable places and people around Kibale National Park, Uganda. Geographical Review, 87, 27-46.

Naughton-Treves, L., Treves, A., Chapman, C. \& Wrangham, R. (1998) Temporal patterns of crop-raiding by primates: linking food availability in croplands and adjacent forest. Journal of Applied Ecology, 35, 596-606.

Newmark, W.D., Manyanza, D.N., Gamassa, D.G.M. \& SARIKo, H.I. (1994) The conflict between wildlife and local people living adjacent to protected areas in Tanzania: human density as a predictor. Conservation Biology, 8, 249-255.

Paterson, J.D. (2005) Residents and immigrants: reactions and perceptions of crop-raiding in Masindi District, Uganda. In Commensalism and Conflict: The Human-Primate Interface (eds J.D. Paterson \& J. Wallis), pp. 74-89. American Society of Primatologists, Oklahoma, USA.

Reynolds, V. (2005) The Chimpanzees of the Budongo Forest. Oxford University Press, Oxford, UK.

Sitati, N.W. \& Walpole, M.J. (2006) Assessing farm-based measures for mitigating human-elephant conflict in Transmara District, Kenya. Oryx, 40, 279-286.

STRUM, S.C. (1994) Prospects for management of primate pests. Revue d'Ecologie-La Terre et la Vie, 49, 295-306.

Thouless, C.R. \& SAKwA, J. (1995) Shocking elephants: fences and crop-raiders in Laikipai District, Kenya. Biological Conservation, 72 99-107.

USDA (United States Department of Agriculture) (2008) Natural Resources Conservation Service: Plant Database. Http:// plants.usda.gov/ [accessed 27 June 2008].

Wallace, G.E. (2010) Monkeys in maize: primate crop-raiding behaviour and developing on-farm techniques to mitigate human-wildlife conflict. $\mathrm{PhD}$ thesis. Oxford Brookes University, Oxford, UK.
Warren, Y., Buba, B. \& Ross, C. (2007) Patterns of crop-raiding by wild and domestic animals near Gashaka Gumti National Park, Nigeria. International Journal of Pest Management, 53, 207-216.

Watanabe, K. \& Muroyama, Y. (2005) Recent expansion of the range of Japanese Macaques, and associated management problems. In Commensalism and Conflict: The Human-Primate Interface (eds J.D. Paterson \& J. Wallis), pp. 400-419. American Society of Primatologists, Oklahoma, USA.

Webber, A.D. (2006) Primate crop-raiding in Uganda: actual and perceived risks around Budongo Forest Reserve. $\mathrm{PhD}$ thesis. Oxford Brookes University, Oxford, UK.

Webber, A.D., Hill, C.M. \& Reynolds, V. (2007) Assessing the failure of a community-based human-wildlife conflict mitigation project in Budongo Forest Reserve, Uganda. Oryx, 41, $177-184$.

\section{Biographical sketches}

SARA S. HSIAo is interested in practical and sustainable methods of conservation, and in working with people to utilize strategies that benefit both local people and wildlife. CAROLIne Ross is a primatologist working on socioecology and human-animal interactions, and is currently conducting long-term research in Gashaka Gumti National Park, Nigeria. Catherine M. Hill is currently researching implications of human population density, changing agricultural policy and practices, and changing land use for peoplewildlife interactions in Uganda. Graham E. Wallace's interests include the mechanisms, measurement, and mitigation of humanwildlife conflict, wildlife behaviour in conflict contexts, and participatory approaches to conservation. 